Forthcoming in Journal of Legal Theory

\title{
Equal Liberty, Non-Establishment and Religious Freedom
}

\author{
Cécile Laborde \\ University College London ${ }^{1}$
}

In South Carolina in the early 1960s, a member of the Seventh-Day Adventist Church, Adell Sherbert, was denied unemployment compensation on the grounds that no 'good cause' justified her unwillingness to comply with her employer's demand that she, like other employees, accept Saturday work. The US Supreme Court reversed the lower court's decision, and found that denying Sherbert's compensation claim violated her rights to religious freedom. Sherbert v. Verner (1963) became a landmark case in the constitutionalisation of religious freedom. Consider, however, two different ways in which Sherbert's religious freedom claim could be justified. On the one hand, one could say (as the Court in fact said) that to condition Sherbert's access to benefit on her willingness to violate a cardinal principle of her faith would be unduly to penalize and burden her rights of religious freedom. On this view, Sherbert has a pro tanto claim to practice her religion freely (absent a compelling state interest). On the other hand, one could say that denying compensation would entail unjustly discriminating against Sherbert who, unlike similarly situated workers, faces an unfair dilemma: either complying with the job's requirements or obeying the demands of her faith (and losing her claim to compensation). On this view, Sherbert has a comparative claim to be treated on fair, equal terms with others. This second justification draws on what I propose to call an egalitarian

\footnotetext{
${ }^{1}$ This paper was written during my stay as a Fellow in the School of Social Science at Princeton's Institute for Advanced Study (2010-2011). I am grateful to fellow participants in the Secularism seminar for stimulating discussions throughout the year. Earlier drafts were presented in Paris, Cambridge, Barcelona, Essex, and at the UCL Colloquium in Legal and Political Philosophy. For useful discussions and comments, I would like to thank Eric Barendt, Corey Brettschneider, Paul Bou-Habib, Clare Chambers, Avigail Eisenberg, Michael Freeman, Bob Goodin, George Letsas, José Luis Marti, Aileen McColgan, Ronan McCrea, Colin McLeod, Véronique Munoz-Dardé, Serena Olsaretti, Avia Pasternak, Tom Pink, Jonathan Quong, Pierre Rosanvallon, Elizabeth Shakman Hurd, Micah Schwartzman, Joan Scott, Jonathan Seglow, Jeff Stout, Winni Sullivan, Charles Taylor, John Tasioulas, Laura Valentini, Albert Weale, Stuart White and Andrew Williams. Thanks also to the Journal's editors and referees, including Steven D. Smith, for their insightful advice. My stay at the Institute for Advanced Study was funded by the Florence Gould Foundation.
} 
theory of religious freedom. It is the coherence and plausibility of egalitarian theories of religious freedom that this essay puts to the test.

The essay is divided into three sections. The first section lays out the rationale and structure of egalitarian theories of religious freedom, and explains their initial appeal in light of progressive norms of non-discrimination and equality - between majority and minority religions on the one hand, and between religious and non-religious moral commitments on the other. The second section offers a detailed account of the most developed egalitarian theory of religious freedom so far, that proposed by constitutional theorists Christopher Eisgruber and Lawrence Sager in their 2007 book, Religious Freedom and the Constitution. ${ }^{2}$ Their theory of 'equal liberty' explicitly denies that religion is entitled to special and unique treatment in law, above and beyond that granted to comparable commitments and practices. The third and last section demonstrates that their theory fails on its own terms. It further suggests that this failure is symptomatic, not only of the narrow First Amendment doctrinal constraints within which the authors operate but, more widely and more interestingly, of the difficulty encountered by liberal theory in fitting the concept of religious freedom into a broadly egalitarian framework. This essayr is part of a larger project which attempts to set out the precise (if limited) sense in which egalitarian political philosophy should treat religion as special, or uniquely special.

\section{I}

\section{Egalitarian Theories of Religious Freedom}

Theories of religious freedom ask what the status of religious freedom, qua religious, is in the liberal state. Should religious believers be exempted from the application of laws that burden their conscience? Which forms of state support or endorsement of religion, if any, are permissible? Schematically, we might say that the first question relates to the Free Exercise clause of the First Amendment of the US Constitution ('Congress shall make no law... prohibiting the free exercise' of religion) and the second question relates to the Establishment clause ('Congress shall make no law respecting an establishment of religion'). Not surprisingly, doctrinal and political disagreements about these clauses have fuelled a long-standing and vibrant - if somewhat narrowly self-referential - tradition of scholarly commentary about religious freedom among US constitutional theorists. In

${ }^{2}$ Christopher Eisgruber and Lawrence Sager, Religious Freedom and the Constitution. Cambridge Mass.: Harvard University Press, 2007. 
this piece, I shall liberally draw upon this rich tradition, both in its free exercise and in its nonestablishment dimensions, as well as pointing to the broader relevance of the questions it asks. In particular, I shall use the US doctrinal debates to distill and explicate a distinctive, new approach, which I call an egalitarian theory of religious freedom. ${ }^{3}$ Egalitarian theories of religious freedom describe a family of views that hold that religious freedom is not a distinctive freedom and that it should be treated under a more general equality-based regime. The special and unique place of religion is indefensible in light of the ideal of equality between citizens. Religious beliefs and activities might be specially protected, but not uniquely so: if and when they are, it is as a sub-set of a broader category of respect-worthy beliefs and activities. Egalitarian theories of religious freedom are based on three main premises. As I shall show, each premise breaks with well-established traditional views about the special and unique nature of religion (either from an 'accommodationist' or from a 'separationist' perspective ${ }^{4}$ ) and tallies with broader recent developments in egalitarian legal and political theory. I now explicate these points, in relation to each of the three premises.

(1) Religious freedom is a sub-category of a more general set of freedoms, such as freedom of speech, association, and privacy, and does not deserve uniquely special treatment.

Egalitarians deny the basic starting point of accommodationists such as Michael McConnel, for whom religious freedom is basic and distinctive; it is the 'first freedom' in the liberal state. ${ }^{5}$ Religious freedom cannot be analogized with, or reduced to, other freedoms, as it serves to protect a uniquely special human good, an autonomous sphere of conscience, ritual and community, from state interference and regulation. ${ }^{6}$ Egalitarians theorists of religious freedom concede that religion

\footnotetext{
${ }^{3}$ The idea of an egalitarian theory of religious freedom is insightfully adduced (though not fully explicated) in Abner S. Greene, 'Three Theories of Religious Equality... and of Exemptions', Texas Law Review, Vol. 87, No. 963, 200, 963-1007. See also Noah Feldman, 'From Liberty to Equality: The Transformation of the Establishment Clause', California Law Review, Vol. 90, No. 3 (May, 2002), pp. 673731.

${ }^{4}$ Accommodationists focus on the Free Exercise clause and argue that religious freedom should be specially protected by the state; separationists focus on the Establishment clause and argue that there should be a 'wall of separation' between state and religion. The two positions are neither mutually incompatible nor exclusive of other interpretations of the two clauses, but they provide a useful focus for my discussion here. For comprehensive literature reviews and classifications, see Kent Greenawalt, Religion and the Constitution, Princeton: Princeton University Press, 2008, 2 Vols., Micah Schwartzman, 'What if Religion is not Special?', Virginia Public Law and Legal Theory Research Paper No. 2012-03.

${ }^{5}$ Michael W. McConnell, 'Accommodation of Religion', Supreme Court Review, 1985, 1-59; Michael W. McConnell, 'The Problem of Singling Out Religion', 50 DePaul Law Review. 1, 5. (2000), 9-12.

${ }^{6}$ For similar views of the special and unique nature of religious freedom, see Douglas Laycock, 'Religious Liberty as Liberty', 7 Journal of Contemporary Legal Issues 313 (1996); Thomas Berg, 'Can Religious Liberty
} 
may be paradigmatic of beliefs, identifications and practices that people have a particular interest in pursuing in their own way, individually or collectively. But they insist that, while religion is a paradigm of those valuable concerns, it does not uniquely capture them. As leading political philosophers have argued, it is the human capacity for moral or spiritual agency, not for leading good lives with a determinate, perhaps religious, content, that should ground the respect that the state owes to persons qua persons. John Rawls, for example, treats free religious exercise as part of a broader notion of 'equal liberty of conscience' that extends both to 'moral and religious claims'.7 More recently, Ronald Dworkin has suggested that religious freedom is not sui generis and is only one implication of a right to 'ethical independence in foundational matters'. ${ }^{8}$ Nor is ethical independence, or moral agency, the only value that religion can be analogized with, or 'reduced' to. Other such 'reductionist' approaches to religion have shown that, for purposes of constitutional protection, religion is not relevantly different from other categories such as speech and association; or - in equal protection and anti-discrimination cases - race and other 'suspect' classifications. ${ }^{9}$

(2) Religious believers may be exempted from some general laws on the basis of non-discrimination, but not on the grounds that religion must be protected qua religion.

Here again, egalitarians challenge a basic accommodationist premise, according to which governments need strong reasons, or 'compelling interests' to justify infringing religious freedom. Failing that, religious believers have a presumptive right to be exempted from the application of general, neutral laws when these unreasonably burden their conscience. Egalitarians deny that religious believers have such a presumptive right. What they are entitled to is a fair scheme of 'equal liberties' guaranteed by the state: they must not be treated differently from similarly situated citizens. They can benefit from specific exemptions from the law when not granting those exemptions would constitute unfair discrimination against them. For example, minority religious

Be Protected as Equality?', Texas Law Review, Vol. 85, No. 5, April 2007; Andrew Koppelman, 'Is It Fair to Give Religion Special Treatment?', 2006 University of Illinois Law Review 571; Steven D. Smith, 'NonEstablishment Under God? The Nonsectarian Principle', University of San Diego Public Law Research Paper No. 04-08, Spring 2004; Abner S. Greene, 'Three Theories of Religious Equality'. More generally, and in a European context, see Rex Ahdar and Ian Leigh, Religious Freedom in the Liberal State. Oxford: Oxford University Press, 2005.

${ }^{7}$ Rawls, Theory of Justice, 206.

8 Ronald Dworkin, Justice for Hedgehogs. Cambridge Mass: Harvard University Press, 2011, 376.

${ }^{9}$ William Marshall. 'Solving the Free Exercise Dilemma: Free Exercise as Expression', 67 Minnesota Law Review, 545 (1983); Michael A. Paulsen, 'Religion, Equality, and the Constitution: An Equal Protection Approach to Establishment Clause Adjudication', 61 Notre Dame Law Review. 311, 317 (1986). 
citizens might be indirectly discriminated if, because of a facially neutral regulation, they do not have the same set of opportunities as majority religious citizens. Egalitarian theories, then, invite systemic comparisons between the terms of accommodation of majority and minority religions.

This is in line with the rise of norms of equality and non-discrimination as unifying norms in national, international and human rights law. These norms have provided a language to challenge structural patterns of cultural, gender, sexual and racial discrimination in Euro-Atlantic societies, notably by bringing to light the hidden, invidious effects of facially neutral, yet culturally biased, institutions, practices and laws. A range of minority religious claims have been re-described as protests of unfair discrimination against practices which - had they been engaged in by majority groups - would presumptively have been tolerated or accommodated. The Canadian legal norm of 'reasonable accommodation', for example, has allowed special exemptions from workplace regulations (uniform, days of rest) to members of minority religions, often with explicit recognition that members of majority religions already benefit from built-in advantage. ${ }^{10}$ The Danish cartoon controversy has brought to light the double standards which permeate free speech doctrine and practice in Europe, with heightened cultural sensitivity towards offense against Christian (and Jewish) feelings unmatched by corresponding empathy towards the harm caused by anti-Muslim speech. ${ }^{11}$ And analogies between demands for the recognition of minority faiths in the public sphere and the de facto public role of Christian churches in many European states have been drawn. ${ }^{12}$

(3) The state must guarantee the equal civic status of all citizens, regardless of the particular beliefs and values they endorse and pursue.

${ }^{10}$ Gérard Bouchard, Charles Taylor, Fonder l'avenir. Le temps de la conciliation. Commission de consultation sur les pratiques d'accommodements reliées aux différences culturelles. Archives nationales du Québec, 2008; Cécile Laborde, 'Républicanisme critique, républicanisme conservateur : repenser les " accommodements raisonnables "', Critique Internationale, July-September 2009, 19-33.

${ }^{11}$ See special issue of International Migration, 'The Danish Cartoon Affair: Free Speech Racism, Islamism and Integration', with contributions by Erik Bleich, Tariq Modood, Randall Hansen, Brendan O'Leary, Joseph H. Carens, 2006, 44 (5); Robert Post, 'Religion and Freedom of Speech: Portraits of Muhammad', Constellations, 2007, 14 (1), 72-90; Sune Lægaard, 'The Cartoon Controversy: Offence, Identity, Oppression?', Political Studies, 2007, 55, 481-498; Talal Asad, Judith Butler, Wendy Brown and Saba Mahmood, Is Critique Secular? Blasphemy, Injury, and Free Speech. Berkeley, University of California Press, 2009; Cécile Laborde, 'Rights, Wrongs and the Right to Do Wrong. Jytte Klausen and the Political Theory of the Danish Cartoon Controversy", Perspectives on Politics, September 2011, 603-605.

12 Geoffrey Brahm Levey, Tariq Modood (eds.) Secularism, Religion and Multicultural Citizenship. Cambridge: Cambridge University Press; 2009; Cécile Laborde, Critical Republicanism. The Hijab Controversy and Political Philosophy. Oxford: Oxford University Press, 2008. 
In relation to the non-establishment clause of the First Amendment, egalitarian theories endorse a stance of 'neutrality' towards religious and non-religious citizens. This has different implications for state funding and for state speech. Regarding state funding, egalitarians argue that religious groups pursuing public-interest activities must not be treated differently from non-religious groups merely because they are religious. Here, egalitarians depart from traditional separationist views which object on principle to any channeling of public money to religious groups. Instead of 'no-funding', egalitarians advocate 'even-handed' funding. This even-handed approach, however, cannot be extended to state speech. The state cannot symbolically endorse the symbols and rituals of all religions, but it must decide whether to attach itself to the traditional majority religion - typically Christianity. For egalitarians, the state should generally avoid any endorsement of religion, in order not to convey messages of second-class citizenship or disparagement to minority believers or nonbelievers.

Against the accommodationist view that the Establishment only prohibits coercive entanglement of government with religion, egalitarians point to the unavoidably expressive dimension of law and the state - the fact that non-coercive messages and actions can have an impact on the democratic status of citizens. ${ }^{13}$ The state should not endorse - even non-coercively or symbolically - the rituals and beliefs of particular religious traditions, so that it can be genuinely be the state of all. Such a perspective has emerged in US jurisprudence with Justice Sandra O'Connor's 'Endorsement Test' (which postulates that the state's symbolic entanglement with religion is wrong insofar as it undermines the equal civic status of citizens ${ }^{14}$ ), in political philosophy with Martha Nussbaum's civic and egalitarian interpretation of the Establishment Clause ${ }^{15}$; and through growing awareness, within European constitutional and human rights law, that equal citizenship demands greater religious neutrality of traditionally Christian European public spheres. ${ }^{16}$

In sum, egalitarian theories of religious freedom seek to advance equality between minority and majority religions (by challenging the discriminatory prevalence of majority religious norms

${ }^{13}$ Daniel Brudney, 'On Non-Coercive Establishment', Political Theory, Vol. 33, No. 6, December 2005, 812839; Cécile Laborde, 'Political Liberalism, Religion and the Separation-Establishment Debate', Journal of Political Philosophy, Early View, July 2011; Joshua Cohen, 'Establishment, Exclusion, and Democracy's Public Reason', in Reasons and Recognition (Oxford University Press, forthcoming).

${ }^{14}$ Greenawalt, Religion and the Constitution, Vol. 2, pp. 182-91; Nussbaum, Liberty of Conscience, pp. 229, 253, 265-6, 270.

${ }^{15}$ Nussbaum, Liberty of Conscience.

${ }^{16}$ Ian Leigh, 'The European Court of Human Rights and Religious Neutrality', in Gavin D'Costa, Malcolm Evans, Tariq Modood, Julian Rivers (eds.) Religion in a Liberal State: Cross-Disciplinary Reflections, Cambridge University Press, forthcoming; Peter Danchin, 'Islam in the Secular Nomos of the European Court of Human Rights', Michigan Journal of International Law, Vol. 32, 2011; Ronan McCrea, Religion and the Public Order of the European Union. Oxford: Oxford University Press, 2010. 
and symbols within existing states) and between religious and non-religious beliefs, practices and identities, be they spiritual, sexual, ethical, or racial (by comparing religion with analogous practices and beliefs). ${ }^{17}$ In the rest of this paper, I shall examine in detail how the three premises of the theory are interpreted and combined in an early, groundbreaking work of constitutional jurisprudence, by Christopher Eisgruber and Lawrence Sager.

\section{II}

\section{Eisgruber and Sager's Theory of 'Equal Liberty'}

Religious Freedom and the Constitution is a book-length commentary on recent Religion Clause jurisprudence of the US Supreme Court. Eisgruber and Sager's basic intuition is that religious believers should enjoy 'equal not special liberty'. They start from the reductionist premise that religion should not be seen as 'a constitutional anomaly, a category of human experience that demands special benefits and/or necessitates special restrictions' ${ }^{18}$ Instead, religious commitments should be treated as part of a broader class of 'deep' and 'important' commitments and projects that people care about, whether religious or not. Next, Eisgruber and Sager deny that such commitments and projects, however morally weighty and significant, generate pro tanto rights against the state. The relevant political question is whether the government, in coordinating different life projects, shares burdens fairly among people. ${ }^{19}$ This allows the formulation of a discrimination-centered account of religious freedom: 'persons [should] not be treated unequally on account of the spiritual foundations of their deep commitments'. Contra egalitarian critics of exemptions, ${ }^{20}$ they argue that exemptions might be demanded by the ideal of equality, insofar as a government enacting generally applicable laws 'may be hostile or insensitive to the needs and interests of minority faiths' ${ }^{21}$ It is as members of discriminated or disparaged groups, not as holders of intrinsically valuable religious beliefs and practices, that minority religious believers deserve special consideration under the theory

\footnotetext{
17 More recent egalitarian theories of religious freedom include Charles Taylor \& Jocelyn Maclure, Secularism and Freedom of Conscience. Cambridge Mass: Harvard University Press, 2011; Schwartzman, 'What if Religion is not Special?; Ronald Dworkin, Religion without God (forthcoming).

18 Eisgruber and Sager, Religious Freedom and the Constitution, 6.

${ }^{19}$ Ibid, 202-3.

20 See, for example, Brian Barry, Culture and Equality: An Egalitarian Critique of Multiculturalism. Cambridge: Polity Press, 2001; William Marshall, The Case Against the Constitutionally Compelled Free Exercise Exemption, Journal of Law and Religion, Vol. 7, No. 2 (1989), pp. 363-414.

${ }^{21}$ Eisgruber and Sager, Religious Freedom and the Constitution,, 202-3.
} 
of equal liberty. This concern for equality, finally, extends to the Establishment question of whether the state can permissibly provide either financial or expressive support to religious groups. Eisgruber and Sager insist that the clause should be interpreted as prohibiting the 'advantaging or disadvantaging [of] persons or groups because of the spiritual foundations of their deeply held beliefs and commitments'. This entails even-handed financial support to religious and non-religious groups providing comparable services; as well as the strenuous avoidance of expressive endorsement by the state of majoritarian beliefs, rituals, or symbols in its own displays, ceremonies and institutions. The theory of equal liberty fits neatly within a broader trend within First Amendment jurisprudence, which tends to de-constitutionalize religion and seek standards of neutrality between religion and non-religion. This trend is exemplified, in the Free Exercise context, by the 1990 Employment Division v Smith decision (which claimed, contra Sherbert, that there is no presumptive right of religious exemption from generally applicable laws) and in the Establishment Clause context, by the 'equal access to government places and money' principle which motivated the Zelman v. Simmons-Harris 2002 decision (authorizing the provision of tuition vouchers channeled to religious as well as secular public schools). ${ }^{22}$ In the next two sub-sections, I show that equal liberty provides a prima facie plausible analysis of recent Free Exercise and Non-Establishment cases, respectively.

Eisgruber and Sager disagree with accommodationists who hold that religion is a uniquely valuable human good that deserves special protection. To treat religion more favorably than comparably deep secular interests would be unfairly to discriminate against the latter on sectarian grounds. Religious freedom, they claim, will legitimately flourish in a society where all members benefit from general rights of free speech, personal autonomy, associative freedom, and private property. ${ }^{23}$ To be sure, the freedoms that such rights protect can be regulated by legitimate state legislation, provided its burdens are shared fairly. For example, taxation and zoning regulations are general burdens that should fall on all, including churches. ${ }^{24}$ However, Eisgruber and Sager suggest that other, more specific legislation might have been designed with insufficient regard for their unfairly disproportionate impact on religious interests. Such interests should not be privileged as religious, but instead protected on similar terms as comparably serious non-religious interests. ${ }^{25}$

22 On the idea of neutrality between 'religion' and 'non-religion', see William Marshall, 'What Is the Matter With Equality?: An Assessment of the Equal Treatment of Religion and Non-religion in First Amendment Jurisprudence', 75 Indiana Law Journal, 193 (2000).

${ }^{23}$ Eisgruber and Sager, Religious Freedom and the Constitution, 4.

${ }^{24}$ Ibid, 88.

25 Ibid, 90 . 
Three different cases of application of this principle in Eisgruber and Sager's discussion can be distinguished. In the first set of cases, the contested law already provides for exemptions for nonreligious interests, to which minority religious interests can easily be analogized. Eisgruber and Sager use the example of Muslim policemen who challenged the Newark police department's requirement that officers be clean-shaved, on the ground that their faith demanded that they wore a beard. ${ }^{26}$ Given that the Newark department already exempted officers with skin disorders, such as folliculitis, that made shaving painful or promoted infection, its refusal to accommodate the Muslims' request constitutes a failure of equal regard.27 In the second set of cases, the contested law does not directly provide exemptions, but is applied against a broader regulatory background which advantages mainstream or majoritarian interests. The Sherbert decision falls into this category. The state of South Carolina had strict Sunday closing laws, which meant that mainstream Christians were not forced to choose between exercising their religious rights and performing the demands of their job. So Adell Sherbert was discriminated against when her claim for compensation was denied. ${ }^{28}$ In the third, and most complicated, set of cases, the contested law is facially neutral and generally applicable. Here, Eisgruber and Sager suggest that government may be held to a standard that measures a claim for a religious exemption against hypothetical exemptions. For example, in the 1988 Lyng case, the Supreme Court considered Native American claims that construction of a logging road on federal land would disrupt vision quests, sacred rituals that depend on isolation and immersion in wilderness. There were no ready-made comparisons, but Eisgruber and Sager speculate that the Forest Service would not have constructed the road had mainstream religious ('a site sacred to a small but well-acknowledged group of Catholics or Orthodox Jews') or secular ('killing off some of the last great redwood trees') interests been at stake. In light of that hypothetical comparison, they say, the case is revealed as a problem of unjust inequality that should have been decided in favor of the plaintiffs. ${ }^{29}$ In sum, through a creative use of analogical and hypothetical reasoning, Eisgruber and Sager suggest that, even though religious interests are not presumptively entitled to unique constitutional immunity from otherwise valid laws, they deserve robust constitutional protection on the basis of equality. It is because minority religious interests are

\footnotetext{
${ }^{26}$ Fraternal Order of Police Newark Lodge v. City of Newark, 1999

${ }^{27}$ Eisgruber and Sager, Religious Freedom and the Constitution, 89.

28 Ibid, $14-5$.

${ }^{29}$ Ibid, 92.
} 
'vulnerable to hostility and neglect' that they should receive special solicitude. ${ }^{30}$ The underlying value of such an anti-discrimination approach is 'parity, not advantage'. ${ }^{31}$

A similar approach, rooted in the value of Equal Protection, is further applied by Eisgruber and Sager to the Establishment clause. They deny that the ban on the establishment of religion should be interpreted as singling out religion for special treatment. Instead, as we saw, they claim that establishment is wrong insofar as it means treating people differentially on grounds of their beliefs and commitments. ${ }^{32}$ Regarding state funding, Eisgruber and Sager reject both the separationist blanket ban on state support of religious activities and services and the accommodationist partiality towards faith-based, religiously-motivated teaching and charity. ${ }^{33}$ They argue that if two organizations, one religious and one non-religious, provide public goods on an equal basis, it would be discriminatory for the state to fund the former and not the latter. For example, they broadly agree with the Court's reasoning in the landmark Zelman decision that authorized the Cleveland school authorities to distribute educational vouchers to parents, who can use them either in religious or in public (secular) schools. ${ }^{34}$

Next, the issue of state speech is found to raise 'a different kind of equality-concern: the worry that by sponsoring religious displays or ceremonies, the government affiliates itself with or endorses a particular theological perspective and implicitly disparages other ones' ${ }^{35}$ While the state may fund religious and non-religious organizations on an equal basis, it cannot be similarly evenhanded in the choice of the symbols, rituals and ceremonies it promotes in its institutions. Eisgruber and Sager follow O'Connor's Endorsement Test, arguing that governmental expressive action is impermissible if it creates a perception in the mind of a 'reasonable observer' that the government is either endorsing or disapproving of religion. ${ }^{36}$ For example, they object to the phrase 'under God' in the Pledge of Allegiance, arguing that non-denominational references to God are alienating not only for agnostics and atheists but also for polytheists and non-deistic believers. ${ }^{37}$

What, however, is wrong with governmental endorsement of religion, as opposed to other views and symbols with equally controversial expressive content? The state, after all, is not barred

\footnotetext{
30 Ibid, 52.

31 Ibid, 59.

32 Ibid, 70 .

${ }^{33} \mathrm{Ibid}, 17$.

${ }^{34} \mathrm{Ibid}, 212-215$. In the particular case of Cleveland, however, they note that the absence of good-quality public schools provided insufficient options for parents, and generated an unfair advantage to the religious schools.

${ }^{35}$ Ibid, 19.

36 Ibid, 122.

37 Ibid, 150-152.
} 
from promoting patriotic rituals, teaching Hegel and sexual education in its schools, or sponsoring the causes of anti-racism, anti-socialism, feminism, or the death penalty. Eisgruber and Sager recognize that the singling out of religion for non-establishment purposes is a challenge to their egalitarian theory of religious freedom. To address it, they explain that the suspect constitutional status of religious practices and beliefs must be related to their 'social meaning' in American culture, where 'important constituents of identity - most notably, race and religion - ... function as especially significant markers of social division'.38 It is because of the sociological and cultural features of religions - "their comprehensiveness; their tendency to treat people as either "in" or "out"; their use of symbol and rituals to signal who is "in"; and, finally, the profound stakes they attach to the status of "in" or "out" 39 - that they are specially vulnerable to invidious discrimination or neglect by majorities. Specially, but not uniquely so. Consistent with their egalitarian, reductionist approach to religion, Eisgruber and Sager find themselves disposed to extend the ban on state endorsement of religion to patriotic pledges, pro-heterosexual slogans ${ }^{40}$, and more generally to the teaching of deeply controversial political 'orthodoxies' in schools. ${ }^{41}$ For them, the non-establishment clause should be read in light of the Equal Protection paradigm: just as the officially sanctioned separation between the races carried a message of inferiority and disparagement to Afro-Americans, likewise, the public endorsement of religion carries a special charge or valence given the role of religion in defining civic identity in the US. 42

This brief synopsis of the main arguments put forward in Religious Freedom and the Constitution should suffice to suggest that the text opens up intriguing theoretical avenues of reflection about the normative foundation of religious freedom. Here is a theory that promises nonnegligible levels of protection for minority religious interests, while denying the need to grant any special privilege to religion as such. This is an attractive proposition for egalitarians, who worry that formal legal equality leaves minority interests at the mercy of majoritarian preferences; yet see little justification for a McConnell-style privileging of religious interests qua religious. Does the theory work, however? In the next section, I show it does not - and I ask what the implications of this failure for the broader ambitions of egalitarian theories of religious freedom are.

\footnotetext{
${ }^{38} \mathrm{Ibid}, 128$.

${ }^{39} \mathrm{Ibid}, 164$.

40 See Christopher L. Eisgruber \& Lawrence G. Sager, 'Chips Off Our Block? A Reply to Berg, Greenawalt, Lupu and Tuttle', 85 Texas Law Review, 1273, 1274 (2007). They argue that a municipal sign such as 'Finneville - a Town for Straight Folks' would be unconstitutional on this ground: 'race, sex and sexual orientation should all be constitutionally protected against disparagement'.

${ }^{41}$ Eisgruber and Sager, Religious Freedom and the Constitution, 170.

42 Ibid, 126.
} 


\section{III}

\section{Equality of What?}

If equality is not to be an empty notion, as Peter Westen and Joseph Raz suspect it is ${ }^{43}$, theories of equality and non-discrimination must specify in respect of what people must be treated equally. Such theories, that is, are not self-standing: they rely on a prior account of which relevant features of existing state of affairs are to be the proper object of comparative evaluations of unfair treatment. For example, it would be implausible to assert that marriage laws unfairly discriminate against business associates or frequent tennis partners, just by virtue of those couples being excluded from its benefits. By contrast, they can be said to discriminate against same-sex couples insofar as the latter exhibit the valued features (intimacy, stability, commitment) which marriage is supposed to protect. Or, alternatively, marriage laws can be said to be indefensible in the first place because they arbitrarily single out, protect and privilege values associated with the traditional family and a conservative social order, and therefore discriminate against non-conventional families and singleperson households. In sum, to be able to claim that tennis partners, same-sex couples, or single parents are discriminated against by marriage laws, we need to provide both (i) an account of the features singled out and promoted by those laws and (ii) an account of what it means to be 'similarly situated' in relation to these features.

Unfortunately, Eisgruber and Sager fail to appreciate the depth of this problem and this, as I shall show, proves fatal to their theory. It is relatively easy for them to build a formally egalitarian case for the extension of existing benefits of protection from religious majorities to religious minorities. Yet, ultimately, they cannot avoid engaging in a more speculative enquiry: that of specifying the relevant features or criteria that are protection-worthy in the first place. Their valiant reductionist search for non-religious analogies to the treatment of religion ultimately fails, as they end up re-affirming precisely what they seek to deny: namely, the uniquely special nature of religion. This failure should not be surprising, in light of the narrow remit of their doctrinal project. For the most part, they are content to analyze and reconstruct the coherence of US First Amendment jurisprudence, which itself assumes (rather than explicates or justifies) the special status of religion. This doctrinal straightjacket limits constitutional lawyers' imagination of what a genuinely

\footnotetext{
${ }^{43}$ Peter Westen, 'The Empty Idea of Equality', Harvard Law Review, Vol. 95, No. 3 (Jan., 1982), pp. 537-596; Joseph Raz, The Morality of Freedom. Oxford: Clarendon Press, 1986, p. 240.
} 
egalitarian, 'post-secular'44 state might look like. In particular, Eisgruber and Sager underestimate the radical implication of their own normative commitment, that no person should be disvalued on account of the spiritual foundations of their important principles.

In what follows, I argue that their analysis either fails to explain, or takes for granted, or implicitly smuggles back in assumptions about the specialness and uniqueness of religion. And insofar as much liberal political philosophy also implicitly relies on what we could call the 'First Amendment paradigm', it is, similarly, partially defective in articulating the normative grounds of its egalitarian commitments. My detailed engagement with Eisgruber and Sager, therefore, is intended to challenge egalitarian political philosophers (with which I am happy to associate myself) to think harder about the 'equality of what?' problem. While egalitarian critics of marriage have engaged with the prior question of the value of marriage, egalitarian theorists of religious freedom still have work to do to account for what, exactly, is the 'religion' in religious freedom. In what follows I explicate these points in relation to the two main areas of controversy discussed by Eisgruber and Sager: exemptions from general laws; and the ban on state endorsement of religion.

\section{a. Free exercise and accommodation}

Eisgruber and Sager's general argumentative strategy is simple. They identify a priori plausible minority religious interests, and then look for reasons to accommodate them. This non-systematic, case-driven strategy partly explains the ad hoc nature of some of their conclusions. Admittedly, when majority interests but not minority interests are exempted by the law, and there is a clear analogy between the opportunity set granted or denied their members, the argument for accommodation is relatively straightforward. This is the case when the law specifically makes provisions for members of majorities both to practice their religion and meet professional demands; yet denies minority members the same opportunity set. ${ }^{45}$ Thus it may be defensible to grant Sherbert compensation benefits given that mainstream Christians are advantaged by Sunday trading laws. More complicated, however, are 'flat rule' laws, which do not entail built-in advantages for any particular group, yet substantially burden minority religious practices. Eisgruber and Sager interpret Lyng, the logging road case, as a case of discrimination by referring to hypothetical alternative interests ('conservationist' or 'Catholic or Orthodox Jews') that would, they speculate, have been better protected than Native American traditional rituals. One may dispute the pertinence of the proposed

\footnotetext{
${ }^{44}$ I use post-secular here in a specific sense, to refer to a state that de-constitutionalises religion and does not apply special and unique legal standards to it.

${ }^{45}$ For a similar account of equal opportunities and religious exemptions, see Jonathan Quong, 'Cultural Exemptions, Expensive Tastes, and Equal Opportunities', Journal of Applied Philosophy, 2006, 23 (1): 53-71.
} 
hypothetical analogies. But more interesting is the authors' strategy. In all cases, they presumptively analogize minority religious claims with interests which are, or should be, exempted. This means that they assume from the outset that religious practices are worth protecting, and they look for already protected (or hypothetically protection-worthy) comparable interests. 46 But what is the criterion of a comparable, or protection-worthy, interest? Why, for example, are religiouslymandated beards analogized with folliculitis - an exempted medical condition - rather than with a non-exempted aesthetic or merely cultural preference?

Eisgruber and Sager's answer is that, for free exercise purposes, religious interests are protected in virtue of being 'deep', 'serious', 'spiritual', 'moral' commitments held by individuals. Although those terms are nowhere clearly defined, they are pivotal to the theory. They allow the authors to draw a wedge between religious freedom and the protection of 'trivial' interests, such as fashion or aesthetic preferences. ${ }^{47}$ They involve what Charles Taylor called a judgment of 'strong evaluation' about the central importance and value of certain belief, practices and purposes. ${ }^{48}$ This strong evaluation is primarily made by the individuals or groups concerned (Eisgruber and Sager explicitly endorse a subjective definition of religion for free exercise purposes ${ }^{49}$ ) but is also checked against wider moral standards (they reject the idea of respect for individual conscience as such, regardless of the content of its injunctions ${ }^{50}$ ). One virtue of their account of the normative grounds of religious freedom is that it sidesteps the sterile debate about whether religious commitments are to be seen as products of 'chance' or 'choice'. ${ }^{51}$ On the strong evaluation view that they favor, religious commitments are neither analogous to unchosen disabilities, nor should they be treated as contingent, negotiable personal preferences. Rather, their normative status merely derives from the fact that individuals closely identify with them, recognize them as theirs, on grounds of their 'deep',

${ }^{46}$ For critiques of Eisgruber and Sager along similar lines, see Jeremy Webber, 'Understanding the Religion in Freedom of Religion', in Peter Cane, Carolyn Evans and Zöe Robinson, eds., Law and Religion in Theoretical and Historical Context. Cambridge: Cambridge University Press, 2008, 26-43, at p. 35; Thomas Berg, 'Can Religious Liberty Be Protected as Equality?', Texas Law Review, Vol. 85, No. 5, April 2007; McConnell, 'On the Problem of Singling out Religion'; Greene, 'Three Theories of Religious Equality', 1006.

${ }^{47}$ Eisgruber and Sager, Religious Freedom, 100-103.

${ }^{48}$ For a thoughtful interpretation of Eisgruber and Sager's theory by appeal to Taylor's notion of 'strong evaluation', see Koppelman, 'Is It Fair to Give Religion Special Treatment?.

${ }^{49}$ Christopher L. Eisgruber \& Lawrence G. Sager, 'Does it Matter What Religion Is?' 84 Notre Dame Law Rev. 807-36.

50 Christopher Eisgruber and Lawrence Sager, 'The Vulnerability of Conscience: The Constitutional Basis for Protecting Religious Conduct' (1994) 61 University of Chicago Law Review, 1245.

${ }^{51}$ See, for example, the essays in Paul Kelly (ed.) Multiculturalism Reconsidered. 'Culture and Equality' and its Critics. Cambridge: Polity, 2002. For an attempt to explore the two dimensions of religion as 'ideas' and as 'identity' see William Marshall, 'Religion as Ideas: Religion as Identity', 7 Journal of Contemporary Legal Issues, 385 (1996). 
'serious', 'spiritual' nature.52 Call this, for short, the Depth Criterion. It is because religious commitments are deep that they deserve special protection in law; and this protection extends to non-religious, comparably deep, commitments. ${ }^{53}$ The Depth Criterion (DC), therefore, is offered as the standard in relation to which a range of commitments and practices, religious and non-religious, are to be treated equally. Adopting a version of reflective legal interpretation, Eisgruber and Sager's method is to go back and forth between existing case law and the value it is supposed to promote (DC), and to seek coherence between the two.

There are, however, fundamental problems with DC as a coherentist standard of interpretation. To start with, DC does not provide a plausible account of the features in virtue of which religion is protected in existing case law. Many religious practices and rituals are performed out of habitual devotion, customary adherence, fidelity to tradition; and do not necessarily exhibit the 'deep, serious, moral' features characteristic of paradigmatic religious freedom cases, such as conscientious objection to military service. Many important rituals - for example, the consumption of the peyote drug in Native American ceremonies - when they are protected, benefit from categorical, not activity-specific, protection. That is, it is because they are categorically described as religious required by a comprehensive tradition, set of beliefs and practices presumptively described as such - that they are protected, not because they directly and singly exhibit the features (depth and

52 But one question they do not address is whether, if people identify with their beliefs, they should not take responsibility for them. In other words, this formulation does not quite get to the heart of the luck egalitarian problem, namely, that people must be compensated for things they cannot change or control; but must take responsibility for their own preferences and beliefs, however these were acquired. The analogy between a medically-required and a religious-required beard, therefore, is not as straightforward as Eisgruber and Sager assume.

${ }^{53}$ The Depth Criterion is in fact a compound of a number of different features associated with religious beliefs, such as the following: they are particularly weighty and serious; they invoke demanding duties of observance; they are rooted in conscience; they are of 'ultimate concern' to individuals; they address profound moral questions; they are comprehensive and cover the whole of life; they are central to individual identity; they are key to personal integrity. Eisgruber and Sager deny that they need to provide a definition of religion, but their understanding of what it means for a belief to be 'deep', 'serious' or 'moral' appeals to one or more of the features which are traditionally associated with religion, yet are also present in secular worldviews too. Note that the implicit definition of religion used is not, however, uncontroversial. To get off the ground, the reductionist approach need to deny that whatever it is that makes religious beliefs 'deep' in the relevant sense (the sense that matters to equality) cannot exclusively lie in their appeal to a divine authority or to the prospects of an after-life. But how do reductionist theorists answer the charge that they are able to analogise religious with secular beliefs only at the cost of denying precisely what makes religious beliefs religious? Reductionists have two answers to this challenge: conceptual (the singled out features do not in fact apply to all commonly recognised religions - many religions are this-worldly and/or non-theistic - and therefore assume an unacceptably sectarian view of what a religion is) and substantive (there is no reason to think that belief in God is what gives moral weight to otherwise deep, respectable, foundational ethical views). 
seriousness of commitment) that make religion itself worthy of protection. ${ }^{54}$ Perhaps it can be said that the ritual-based dimensions of religious observance benefit from special protection insofar as they are embedded within significant practices which themselves, qua religions, meet DC. If this is correct, however, there appears to be an important asymmetry between religious and non-religious commitments. It is difficult to think of comparable non-religious practices that, while not serious, deep or moral in themselves, would benefit from protection in virtue of their connection to a broader, comprehensive set of beliefs and practices which would itself meet DC.

This suspicion of asymmetry is confirmed when we examine more closely how Eisgruber and Sager deal with the cases of what they call 'secular claimants', who demand exemptions from generally applicable laws on non-religious grounds. The plausibility of the theory of equal liberty crucially depends on demonstrating that exemptions can be applied to deep and serious nonreligious claims. Unfortunately, Eisgruber and Sager only provide two examples of such claims, which are very different and importantly limited. The first is that of medical conditions, such as folliculitis in the Newark police case. The example illustrates how, for some purposes, religious claims may be treated by analogy with medical conditions (in some cases, it is useful to analogise burdens on religion with a kind of undue hardship). But it is also meant to illustrate how exemptions on medical grounds can themselves be justified by analogy with existing religious exemptions. To make their case, Eisgruber and Sager are forced to narrow down their original benchmark of comparison - the 'spiritual' foundations of deep 'moral' commitments - into a vaguer and broader benchmark - a 'non-trivial' and 'comparably serious' condition. The upshot is that folliculitis sufferers should be accommodated because their condition is serious and non-trivial.

Here Eisgruber and Sager trade on the ambiguity of their compound definition of DC. This ambiguity - between different senses of 'serious' - allows them to elude the crucial question as to whether it makes a moral difference whether people would (by and large) prefer not to suffer from a disability, whereas they do (by and large) positively endorse and embrace their religious convictions. ${ }^{55}$ The former is serious in that it can negatively affect rightful access to opportunity and advantage, but it is not serious in the moralised sense that the multi-criterial definition of DC embraces. The Newark police case, therefore, cannot serve as an illustration of how DC can be

\footnotetext{
${ }^{54}$ I have explored a version of this problem in another egalitarian theory of religious freedom, that of Taylor and McLure, in Cécile Laborde, 'Protecting Freedom of Conscience in the Secular Age', The Immanent Frame (April 2012). http://blogs.ssrc.org/tif/2012/04/23/protecting-freedom-of-religion-inthe-secular-age/

${ }^{55}$ For the view that taking seriously people's beliefs implies asking them to take (at least some) responsibility for them, see Peter Jones, 'Bearing the Consequences of Belief', Journal of Political Philosophy 1994, 2(1), 24-43.
} 
extended from religious to non-religious cases. Eisgruber and Sager see the problem, yet do not adequately solve it. Suppose, they say, that the Newark police department had allowed exemptions for religiously motivated but not medically mandated beards, and imagine a police officer - whom they call 'Officer Beard' - who alleges discriminatory treatment. While they concede that Officer Beard's claim would most likely fall under a Disability Act, they still consider the possibility that he might have been discriminated on religious grounds, because the Newark police department displayed a culpable preference for religiously-motivated obligations. ${ }^{56}$ But note how the argument shifts the ground of justification. Instead of showing that both religiously motivated and medically required beards are relevantly similar in relation to the DC standard, the authors now merely postulate, without argument, that dissimilar treatment is - culpably - discriminatory.

The second, more plausible illustration of a non-religious application of DC concerns cases of conscientious objection to military service on secular pacifist grounds. Here Eisgruber and Sager are on safer grounds. In two important Vietnam war decisions, Seeger and Welsh, the US Supreme Court exempted secular pacifists from military service on the ground that they had 'a sincere and meaningful belief which occupies in the life of its possessor a place parallel to that filled by the God of those admittedly qualifying for the exemption'.57 Unsurprisingly, the Seeger jurisprudence has become a point of reference for egalitarian theories of religious freedom, as a paradigmatic case of conscientious objection extended from religious to non-religious moral commitments by appeal to DC. Unfortunately, the case is exceptional rather than paradigmatic. In Seeger, the Court was interpreting the narrow terms of a statute, rather than addressing the constitutional question of what should count as protected belief for purposes of the Free Exercise clause of the First Amendment. As a result, unsurprisingly, the Seeger jurisprudence has had few applications outside the exceptional circumstances of war. Free Exercise jurisprudence provides for a 'limited island of exemptions in a world of legal obligations' 58 , and judges have been reluctant to extend the constitutional protection of non-religious deep, serious, moral commitments beyond narrowly circumscribed cases of conscientious objection to military service. ${ }^{59}$

\footnotetext{
${ }^{56}$ Eisgruber and Sager, Religious Freedom and the Constitution, 117-118.

57 Ibid, 113-4.

58 Perry Dane, 'Constitutional Law and Religion', in Dennis Patterson, ed., Blackwell Companion to Philosophy of Law and Legal Theory. Oxford: Blackwell, 2010.

59 Smith - the landmark Supreme Court decision of 1990 which overturned Sherbert by positing that there is no constitutional requirement to allow religious exemptions from general laws - did not significantly alter this situation. It was overturned by Congress through the Religious Freedom Restoration Act (RFRA 1993), and only partly re-instated in Boerne. The current situation is that RFRA still has constitutional status at the federal level. Furthermore, even when exemptions are not constitutionally required, they often are constitutionally permitted. There are an estimated 2,000 statutory exemptions from general laws
} 
Tellingly, Eisgruber and Sager's own attempt to provide a less religion-centered account of DC runs into considerable and ultimately fatal difficulties. In an instructive discussion, they consider the hypothetical case of 'Mother Sherbert', a single mother whose deep commitment to her children prevents her from accepting Saturday work. If she is denied unemployment compensation, is Mother Sherbert been treated unfairly, in relation to religiously-motivated Adell Sherbert? Eisgruber and Sager think not, because her claim bears no 'relation to religion'. ${ }^{60}$ This, of course, is questionbegging: the point of the hypothetical analogy was to determine which deep, serious, moral commitments are sufficiently similar to religion to ground a claim for accommodation. Confusedly, Eisgruber and Sager then consider the hypothesis that Mother Sherbert might in turn view her commitment to her children as a 'matter of religious duty' ${ }^{61}$ But this is a different kind of enquiry, which leads them to speculation about whether duties of care to loved ones can ever be interpreted as 'inflexible religious obligations'. Ultimately, Mother Sherbert's deep commitment to her children is, in their view, not comparable to a deep religious commitment, because it is not inscribed within a holistic view of nature and humankind and the meaning of life (this is, presumably, what they have in mind when they write that Mother Sherbert's claim has 'no relation to religion') and/or because it is not an 'inflexible' God-given 'obligation'. This implies that secular claims, even when they meet a cluster of DC criteria, turn out not to meet the specific criteria necessary to trigger protection namely, what we may call the categoricity and the comprehensive worldview criteria, respectively.

While in Officer Beard's case, Eisgruber and Sager narrow DC down to a minimalist criterion of 'seriousness', in Mother Sherbert's case, they expand it to a maximalist criterion of 'categoricity' and 'comprehensiveness'. While this conceptual flexibility allows them to account for existing law, which accommodates disability but not the pursuit of all valuable ethical pursuits, it does not provide a coherent interpretive criterion for it. And it confirms the suspicion that secular claimants, even under their egalitarian theory, face an unreasonably high burden of proof. Secular pacifist Seeger fits the bill because (arguably) his pacifist convictions had the same scope, categoricity and

in the US (from compulsory vaccinations to prison diets). Out of these, only a few have successfully been extended to non-religious convictions (parents can object to compulsory vaccinations for their children on secular grounds in 20 of the US states, for example). There is, however, an area of potential growth for secular conscientious claims, concerning medical research and controversial medical procedures, such as assisted suicide and stem cell research (where claimants appeal to a secularised view of the inherent dignity of human life). In Canada, where religion has formally no special constitutional status, eco-centric vegetarianism has also been recognised as entitled to 'reasonable accommodation' on the same grounds as religious comprehensive, categorical belief systems (Maurice v Canada, 2002). Cf Taylor \& Maclure, Secularism and Freedom of Conscience.

${ }^{60} \mathrm{Ibid}, 116$.

${ }^{61} \mathrm{Ibib}, 116$. 
depth as familiar religious convictions. But it is difficult to find similar cases and, tellingly, Eisgruber and Sager have not found any. ${ }^{62}$ They conclude their section on hypothetical secular claimants, such as Officer Beard and Mother Sherbert, by conceding that they are hard cases for their theory of equal liberty. Yet as the grounds for accommodation of the former are unclear, and the latter's claim is rejected outright, they might well be fatal cases for the theory. What (Seeger aside) Eisgruber and Sager have not demonstrated is that secular claimants have valid claims of exemptions from generally applicable laws on DC grounds. As a baseline for equal treatment, DC works well to extend existing protections from majority to minority religions, but it does not provide a standard with which to analogise religious and non-religious claims. Either non-religious claims are deep but lack scope and categoricity (Mother Sherbert), or they are not deep in the sense singled out by DC, and something else grounds the claim of discrimination (Officer Beard). In the end, Eisgruber and Sager fall back on the First Amendment paradigm, which grants a categorical protection to something called religion - and this categorical protection turns out to encompass more than the reductionist standard DC.

In light of these difficulties, it is not surprising that Eisgruber and Sager struggle to reconcile their theory of equal liberty with another key feature of the First Amendment paradigm: the existence of sui generis religious exemptions. Sui generis religious exemptions are exorbitant exemptions tailored exclusively for religious organisations. Consider the so-called 'ministerial exception'. It allows religious organizations to be exempted from virtually all regulation of their employment relations (including non-discrimination norms) with clergy. In line with their doctrinal coherentist project, Eisgruber and Sager endorse what they take to be a 'widely-held view' - but they do so by appeal to generic rights of privacy and associational autonomy. To make their case, they draw on a Supreme Court decision (Dale, 2000) which allowed the Boy Scouts of America to be exempt from a New Jersey law that prohibited discrimination against homosexuals. ${ }^{63}$ Unfortunately,

62 They do consider a hypothetical case of unemployment benefit for a pacifist who objects to working in armaments. This is in fact a version of Seeger, applied to the workplace (ibid., pp. 114-16). Tellingly, Eisgruber and Sager distinguish this worker from Mother Sherbert by suggesting that his claim, unlike hers, but like Seeger's, bears 'a relation to religion' - which, again, begs the question by re-introducing a maximalist definition of religion. Intriguingly, they do not consider prima facie hard cases of real-world, secular conscientious objection, such as possible secular parallels to the Wisconsin $v$ Yoder case (1972). Yoder allowed Amish parents to withdraw their children from school aged 14, as an exemption from laws of compulsory education until 16, and did so by appeal to freedom of religion. The Court insisted that such exemptions could only be granted to religious groups - presumably preempting demands for school exemptions from (inter alia) radical leftwing libertarians whose opposition to education was political. It is not clear whether and on which grounds Eisgruber and Sager would disagree, and it is unfortunate that they do not discuss Yoder.

${ }^{63}$ Ibid., 64-5. Boy Scouts of America v Dale (2000). 
as legal scholars have commented, this analogy is doctrinally unsound. Boy Scouts and other nonreligious organizations have no pro tanto right to discriminate in employment: the onus is on them to demonstrate that general antidiscrimination regulation conflicts with their expressive purpose (they rarely succeed, and Dale was rightly controversial). No such demand, by contrast, is made to religious organizations, which benefit from a sui generis, presumptive right to autonomy in the appointment of their leaders. ${ }^{64}$ Try as they might, Eisgruber and Sager fail to account for this special treatment of religion in US law. Similar difficulties, I shall now show, plague their interpretation of the non-establishment clause.

\section{b. Non-establishment and the endorsement of religion}

We have seen that the benchmark for equal treatment, in Free Exercise cases, were the 'deep commitments', religious or not, held by individuals. This benchmark also does some work in Eisgruber and Sager's interpretation of the Establishment Clause, in relation to state funding of different organizations providing equivalent public services. Insofar as associations are free to organize to promote the deep commitments of their members, be they religious or secular in nature, and insofar as government is permitted to offer financial support for the provision of public services (education, welfare, etc) by non-profit associations, it would seem discriminatory to deny funding to a religious organization providing a public service on the same terms as a non-religious one. Arguably, it is in relation to such cases of fair distribution of public benefits that the theory of equal liberty between 'religion' and 'non-religion' is most plausible. ${ }^{65}$ It is in line with recent analyses of the rise of a 'new establishment', characterized by a blurring of the distinction between religious and non-religious services, particularly in the area of the provision of healthcare, which is increasingly construed in spiritual as well as in narrowly medical terms (for example, in US prisons). ${ }^{66}$ Moving from funding to speech issues, however, Eisgruber and Sager are faced with a problem. According to standard constitutional doctrine, the state cannot directly endorse religious commitments in its teachings, symbols and rituals, yet it can permissibly take a position on a range of other deep commitments held by individuals. The special treatment granted to religious statements, therefore,

${ }^{64}$ Ira C. Lupu and Robert W. Tuttle, 'The Limits of Equal Liberty as a Theory of Religious Freedom', Texas Law Review, April 2007, 1-36, at pp. 29-33. A strong doctrine of ministerial exception was recently reasserted by the Supreme Court in Hosanna-Tabor Lutheran Church and School v. Equal Employment Opportunity Commission (January 2012).

${ }^{65}$ Much more remains to be said, however, about what it means for a religious organization to provide a public service 'on the same terms' as a non-religious one. The issue of direct public funding for faithbased initiatives is a complex and controversial one, under-examined by Eisgruber and Sager.

${ }^{66}$ Winnifred Sullivan, 'After Secularization: Governing Through Spiritual Care', unpublished ms, on file with author. 
cannot be explained by their intrinsically 'deep', 'moral' or 'serious' nature. Something else than DC must be doing the work here.

Indeed, when looking for a standard able to shed light on the constitutional prohibition of state religious speech, Eisgruber and Sager point to a different analogy: racial categories and other 'socially divisive markers of identity'. On their interpretation, the reason why the state should not endorse (or disparage) religion, even symbolically, is because, like race, religion has historically functioned as a social category structurally vulnerable to hostility, discrimination, disparagement and neglect. Call this the Vulnerability Criterion (VC). Even though Eisgruber and Sager do not seem to distinguish between the two, VC and DC are importantly different. We could say that they serve to protect different dimensions of the culturally protean and legally elusive phenomenon of religion. For some purposes, religion is treated like race in law - it is defined in relation to the historically sedimented social meanings associated with certain practices and rituals, whereby dominant groups use state power to affirm and entrench hegemonic identities (Protestant, white, male) as normal, and to construe and disparage minority identities as deviant. Witness the process of structural racialisation of religious minorities - Jews, Mormons, Catholics, Muslims - in US history. The analogy between race and religion allows Eisgruber and Sager to construe the wrong of state religious endorsement, from an egalitarian standpoint, as an expressive wrong - a wrong connected to the communication of messages of disparagement or exclusion of minorities.

From a VC perspective, religion functions as a third-person, externally defined category of social classification - by contrast to DC which picks out the first-person, subjective dimensions of religious experience. So, from a VC perspective, a state which proudly proclaims its Christian identity commits an 'expressive wrong', by signifying to minorities that they are outsiders, that they do not belong on the same terms to the political community. Regardless of whether members of those minorities themselves see their religion as a source of deep, serious, moral commitments, official endorsement of the majority religion makes their non-Christian identity relevant - negatively - to their civic status. So, it is exclusionary for a state school to adorn classrooms with Christian crucifixes even if members of non-Christian groups do not see membership in such groups as a source of deep ethical commitment for them. By analogy, US segregation laws disparaged AfroAmericans, not because they denigrated Afro-American culture and ways of life, but because they construed blackness as a negative ascriptive identity, a marker of subordination and inferiority. So what VC picks out, by contrast to DC, are those dimensions of the socially constructed meanings of religion which structurally resemble other suspect categories of oppression and domination, such as race and gender. 
It seems, therefore, that Eisgruber and Sager's theory contains two intriguingly different answers to the 'equality of what?' question. On the one hand, people's ability to act in accordance with their deep beliefs should not be subjected to unequal state burdens (DC) and, on the other hand, the state should not endorse the symbols and rituals of dominant religions for fear of disparaging racial-like minorities (VC). The difference between the two conceptions is obscured by the authors' equal liberty principle: 'no-one should be disparaged on grounds of the spiritual foundations of their deep commitments'. Yet DC and VC point to different benchmarks for the fair treatment of religion: for some purposes, religious beliefs, identities and rituals should be treated like racial and gender identities, from a collective, structural, contextual and third-person perspective; while for other purposes, they should be treated like deep moral, comprehensive commitments, from an individualized, case-by-case and first-person perspective. Does this dualtrack egalitarian reductionist theory, however, tell the whole story of the constitutional treatment of religion? There are reasons to doubt this is the case: Eisgruber and Sager's coherentist project - to demonstrate that, for legal purposes, religion is not sui generis and can be analogised with other social phenomena - is doomed to fail.

Consider the teaching of religion in public schools. On Eisgruber and Sager's interpretation, it is problematic because of the risk of disparagement of non-adherents to the favored religion, in a context of compulsory and state-funded education. However, many controversial topics are taught in schools, which a range of different groups may find objectionable and disparaging; yet First Amendment strictures against endorsement only apply to religion. ${ }^{67}$ In response to this objection, Eisgruber and Sager, as we saw, sought to derive a general anti-orthodoxy principle from existing case-law. There are two problems with this. First, it is doctrinally untenable (legal scholars have doubted that such a principle was ever articulated by the Court ${ }^{68}$ ) and practically inapplicable (it would make a mockery of any project of national public education if only uncontroversial topics could be taught therein). Second, and more interestingly, this enlarged anti-orthodoxy principle does not capture the reason why state-promoted teaching of religion is troubling. Consider the range of topics which may be normally taught or discussed in schools: anti-racism, sexual education, the legitimacy of foreign wars, environmentalism, the death penalty, the historical treatment of Native Americans, Marxist philosophy, and so forth. No doubt many citizens feel excluded and offended by such teachings, and no doubt it would be discriminatory for the state to include or exclude private speakers from a public forum based on their positions about these issues. Yet it is not a priori

\footnotetext{
${ }^{67}$ Lupu \& Tuttle,' The Limits of Equal Liberty'; Greene, 'Three Theories of Religious Equality'. ${ }^{68}$ Greene, 'Three Theories of Religious Equality', 980-84.
} 
impermissible for the state to inculcate political 'orthodoxies' (such as gender equality and antiracism) nor to debate controversial topics (such as Marxism or the death penalty). But it is impermissible for US governmental institutions to teach religious topics. Religious beliefs, in particular, may not be presented as statements about the truth (religious instruction) nor can they, generally, be subjected to critical discussion (whether secular or theologically-based). ${ }^{69}$ This is because state schools - and more generally, political authorities - are woefully incompetent judges of truth in religion, in a way in which they are not in relation to other controversial topics. ${ }^{70}$

What the ban on state teaching of religion refers to is a kind of epistemic integrity which prevents the state from interfering in matters that are not within its remit. This, as Steven Smith has recently reminded us, is the original meaning of the separation between state and church, which assumed the existence of two separate jurisdictions competing for sovereign power over and across their allocated 'this-worldly' and 'other-worldly' spheres of competence. ${ }^{71}$ Such a two-realm conception of religious freedom is precisely what the egalitarian theory of religious freedom seeks to dispense with. But, fascinatingly, Eisgruber and Sager's heroic attempt does not succeed in displacing this older, sui generis view of religion in favor of their own reductionist, individualistic and egalitarian approach. Neither the ban on the teaching of religion in US state schools, nor religious exemptions from employment laws (and notably the ministerial exception) can be accounted for by their theory of equal liberty. Religious associations, qua religious, suffer burdens (under Non-Establishment) and enjoy benefits (under Free Exercise) which no comparable association has at its disposal (because there is no comparable association). Only they can claim a kind of epistemic integrity which regulates their relationship, qua collective agents, with the collective agent of the state. Call this the Integrity Criterion (IC). For some (admittedly limited) purposes, religion is singled out and treated in law in a sui generis way, as an autonomous sphere of human life and action, regulated by specific doctrines and standards.

Note that IC, by contrast to VC and DC, does not provide a benchmark for comparison; rather, it is one criterion which picks out the special and unique - non-reducible - features of the legal treatment of religion. A theory, such as Eisgruber and Sager's, which provides no plausible justification of its own for this singling out, nor considers the possibility that it is irreconcilable with

\footnotetext{
${ }^{69}$ However, state schools can permissibly teach about religion in two ways: they can present them as historical and sociological objects of study; and they can criticize religiously-inspired commitments when these openly contradict basic rights and democratic principles.

${ }^{70}$ Greenawalt, Religion and the Constitution, Vol. 2, 466-7. For an extended and subtle discussion, see also Kent Greenawalt, Does God Belong in Public Schools? Princeton: Princeton University Press 2005.

${ }^{71}$ Steven D. Smith, The Disenchantment of Secular Discourse. Cambridge Mass.: Harvard University Press, 2010, Chapter 4.
} 
the theory's far-reaching egalitarianism, is at best an incomplete, and at worst a self-contradictory, theory of religious freedom. Eisgruber and Sager simply cannot hold on both to their project of doctrinal coherence and to their reductionist interpretation of religion. The US Constitution does give a special place to religion, and this cannot be accounted for by drawing analogies, however creative, between religion and other social beliefs and practices. Neither the Depth Criterion (DC) nor the Vulnerability Criterion (VC) succeed in providing a plausible currency of equality between religious and non-religious claims; and the Integrity Criterion (IC) puts the very possibility of comparability between them into question.

In this essay, I have argued that Eisgruber and Sager's theory fails on its own terms. This failure, I have further suggested, is symptomatic of the difficulties encountered by liberal theory in fitting the concept of religious freedom into an egalitarian framework. At this point, a legitimate objection may be formulated. Could a more philosophically ambitious, less narrowly legalist liberal egalitarian theory avoid the pitfalls of Eisgruber and Sager's narrowly coherentist project? After all, why should liberal egalitarian philosophers be constrained by the limitations of US constitutional theory? The answer to this question is that something like the First Amendment paradigm - namely, the view that religion must be uniquely protected and contained - also shapes, albeit in more subtle and discrete ways, much of contemporary liberal egalitarian theory.

There are two desiderata that egalitarian theories of religious freedom must meet if they are not to run into the insuperable problems encountered by Eisgruber and Sager. First, they must not be doctrinally coherentist. If religion really is only a sub-set of a broader class of beliefs, identities or practices, which should be treated on a par with them, then large areas of existing law (which carve out special protections or special prohibitions for religion) become normatively indefensible. Fortunately, normative philosophers, by contrast to constitutional lawyers, are not beholden to doctrinal coherence. So they can bite the bullet and argue that the special treatment afforded religion qua religion in the law has lost any normative purchase in contemporary society. This would allow them to explain away constitutional tenets such as the special ban on state aid to religion and the ministerial exception as archaic remnants of the discredited 'two-realm' theory. Instead, they would start from the idea that the liberal state must be decidedly post-secular and take account of the deep pluralism of values, ideas and identities, both religious and non-religious, in contemporary societies. Second, egalitarian theories of religious freedom must be more complexly egalitarian. We saw that 
Eisgruber and Sager struggled to answer the 'equality of what?' question, and alternated between different standards - depth and vulnerability, for example - in their search for appropriate benchmarks of egalitarian comparison. Ultimately, their theory seemed too ad hoc, because it failed to include factors such as depth and vulnerability into a more complex metric of equality, and into a broader theory of justice.

At least two liberal egalitarian theories, those of Rawls and Dworkin, prima facie meet both desiderata. Although they differ in important ways, they both avoid many of the problems which plagued Eisgruber and Sager's approach. Liberalism, for them, is not a coherentist project and is not textually bound by US First Amendment jurisprudence. The liberal state should be committed to show equal respect to all individuals, regardless of the particular conceptions of the good or ethical views, religious and secular, which they hold dear. Rawls's and Dworkin's liberalism, therefore, is more radically reductionist than Eisgruber and Sager's constitutional theory. It is also more complexly egalitarian: it combines an account of equal basic rights and liberties (including freedom of conscience) with a commitment to socio-economic equality of opportunity. It further asks which 'morally arbitrary features' or instances of 'bad luck' (such as disability, race and other markers of vulnerability) unfairly prevent individuals from accessing equal opportunities. This more complex egalitarianism offers a promising framework for integrating DC and VC, by disaggregating the concept of religion into distinct values within an overarching theory of justice.

Such a complexly egalitarian theory, embedded in a broader theory of liberal justice, is a more cogent way of defending the post-secular state than Eisgruber and Sager's constitutional theory. What remains to be assessed is whether normative post-secular liberalism entirely succeeds in displacing the traditional liberal commitment to a uniquely special separation between state and religion. There is little doubt that something called religion - a complex notion involving faith and belief, conscientious duty, a sense of the sacred, valued communal practices, comprehensive scope, ultimate moral concern, the pursuit of extra-temporal goods, a divine authority, totalizing social institutions, historically salient collective identities, divisive and controversial belief systems, and so forth $^{72}$ - has provided the structural template out of which liberal political philosophers, from John Locke onwards, have conceptualized and justified the liberal state. As a result, the Euro-Atlantic conception of the secular state, as Amy Gutmann has acutely noted, is grounded in an ideal of 'two-

\footnotetext{
72 In this paper, I have deliberately avoided providing a precise definition of religion. What should be apparent is that, while many authors work with a common-sense, 'you-know-it-when-you-see-it' understanding of the notion, they select, for the purpose of their analysis, very different features of it. In future work, I aim to reformulate a viable egalitarian project which dispenses with the category of religion altogether and instead pursues a strategy of dis-aggregation of the compound concept of religion.
} 
way protection' - protection of religion from the state, and protection of the state from religion. ${ }^{73}$ Post-secular egalitarian liberalism attempts radically to dispense with two-way protection. But does it succeed in this radical endeavor, and should it? My hunch is that, much like Eisgruber and Sager, normative liberal philosophers yet have to consider the full implications of the (still embryonic) post-secular political theory. In particular, they will need to reflect further on questions such as: is anything of value lost in the reduction of religion to 'conceptions of the good' or 'ethical views'? Can the liberal norm of religious non-establishment be subsumed under a general principle of liberal neutrality? In what sense, if any, is liberal justification, and public reason, secular? In the end, I suspect, political philosophers, not only constitutional lawyers, will have to grapple with the complex epistemological, historical, and ethical questions raised by the legal-political construction of religion in the Euro-Atlantic liberal tradition.

${ }^{73}$ Amy Gutmann, Identity in Democracy. Princeton, NJ: Princeton University Press, 2003, pp. 158-9. 